\title{
Disciplining Global Society ${ }^{1}$
}

Tony Evans, University of Southampton

\begin{abstract}
One of the puzzles of the current era is the divide between optimists and pessimists on the question of human rights. The prominence of human rights on the international political agenda sustains the optimist's hopes for the future, while pessimists point to continued and widespread reports of civil, political, economic, social and cultural violations. This article looks at the tensions and apparent contradictions between these two approaches. Following a discussion on the construction of global human rights discourse(s), the article concludes that the pretensions of law act to mask the socioeconomic normative framework that acts to discipline global society.
\end{abstract}

One of the puzzles of the current era is the divide between optimists and pessimists on the question of human rights. ${ }^{2}$ Both optimists and pessimists within the human rights discourse begin by noting significant changes in the spatial reach and intensity of networks of social relations. The increasing activity of social movements, nongovernmental organizations, interest groups, corporations, financial institutions, indigenous peoples' organizations and citizens groups engaged in global discourses on every aspect of our social, economic, political and cultural lives testifies to these changes.(Cox, 1999; Held, et al., 1999; Linklater, 1998) However, having accepted this general observation, optimists and pessimists part company; optimists asserting that the new freedoms found in the processes of globalization offer ever greater opportunities for protecting human rights and pessimists asserting that globalization provides a new context for further exploitation and subsequent violation of rights (Scholte, 1996; Spybey, 1996)

For optimists, the intensity and ubiquity of social networks promises to increase the demand to secure human rights, democracy and environmental protection for all. While in the post-World War II period of political realism arguments over sovereignty and the national interest often stood in the way of making progress on human rights, optimists argue that, today, such arguments are untenable. The greater interconnectedness characteristic of globalization, and increasing demands for transparency, mean that the demand for human rights cannot be circumvented. The vast body of international human rights law created in the last few decades is seen by optimists as the formal expression of normative changes that place human rights at the centre of global political life. For

\footnotetext{
${ }^{1}$ This paper was developed from a keynote address delivered at the conference "Human Rights in a Globalizing Era?,” organized by the Centre for Studies in Social Justice, University of Windsor, Ontario, Canada, 4-6 August 2005. I am grateful to the conference participants who made useful comments following the address.

${ }^{2}$ The author gratefully acknowledges the support of the Leverhulme Trust, which partially funded the research for this article.
} 
optimists, the new order represents "power to the people" in as far as human rights offer the oppressed, the excluded, the victims of tyrannical governments, and those engaged in the politics of identity an opportunity to gain the "moral high ground" in the struggle for emancipation and freedom.

For pessimists, on the other hand, conditions of economic globalization offer an opportunity to exercise "power over people," by promoting particular modes of thought and practice that support the interests of global capital. From this perspective, the freedoms described and "normalized" within the practices of globalization accentuate processes of inclusion and exclusion, equality and inequality, to the detriment of human rights (UNDP, 1997; UNDP, 1999). Pessimists feel vindicated, for instance, when a leading member of a prominent investment corporation, commenting on the possibility of human rights within the current global order, remarks that the "great beauty of globalization is that no one is in control” (Hormats, 1998). While the international legal regime of human rights includes a wide spectrum of rights, the values associated with globalization remain the dominant mode of thought that guides political, social and economic action. The discourse of human rights may have stimulated the creation of international law, but the context in which rights must be promoted denies the possibility of achieving any significant and lasting progress.

This article argues that the hegemony of international law obfuscates the practice of human rights as a discourse of both freedom and oppression. It begins by looking at the structure of modern human rights discourses: legal, philosophical, and political. Through this analysis, it is argued that the philosophical and political discourses of rights have been largely displaced by legal discourse, leaving the impression that all the major philosophical and theoretical arguments have been resolved. The argument then turns to look at the context in which human rights discourses and practice are conducted in the current period, arguing that the context of economic globalization is largely overlooked in the legal discourse of rights. As a third section argues, this is because the legal discourse privileges rights associated with "market-discipline" and the interests of those most closely associated with economic globalization. Finally, some conclusions are drawn.

\section{The Discourse(s) of Human Rights}

The starting place for seeking an understanding of the tensions between optimists and pessimists is to recognize that the modern human rights discourse is predominately a discourse of international law. NGOs, international organizations, and states all accept that the human rights regime is a legal construct. While the philosophy of rights and the politics of rights do retain some foothold within the literature, the overwhelming focus remains on legal instruments, practices and institutions. Further evidence of this is seen in the predominant legal approach adopted in university curricula, where human rights is taught mostly within departments of law. (Freeman, 2002).

This justification for presenting the promotion and protection of human rights as a legal discourse has attracted little comment (Chimini, 1999; Mieville, 2006). This could, of course, be explained as mere oversight. However, given repeated claims that human rights are the "idea of our time," and widely voiced assertions that human rights represent a universal and eternal truth which is now recognized by international society, the lack of 
reflection on the authority, relevance and hegemony of international human rights law remains a puzzle.

This is not to argue that the literature consistently fails to engage in criticism of the international human right regime. On the contrary, criticism is not hard to find, particularly criticism that is aimed at the failure of international society to solve the problems associated with compliance and implementation. However, these criticisms are commonly concerned with refining, polishing, and elaborating accepted norms, standards, and practices in an attempt to make the regime more elegant, sophisticated, imposing and magisterial. As one commentator has observed, it is criticism undertaken by committed human rights experts, resolutely “advancing the faith” (Chandler, 2002).

What this approach conceals is a lack of critique. While criticism is confined to arguments about particular theories, philosophies, beliefs, ideologies, and regimes, critique is more concerned to investigate the ways in which these claims to truth are achieved, legitimated, and presented as the authoritative guide for action. If criticism is thought of as part of a technical debate, a debate intended to refine particular truths, critique is concerned with the "politics of truth" itself (Foucault, 1996). As such, critique is concerned to expose the interests served by the production and maintenance of particular truths, and the processes that enable some forms of knowledge to be accepted as complete and legitimate while other forms are labelled partial and suspect. In this sense, critique occupies a limited space within the literature (Rouse, 1994; Taylor, 1995).

The dominant legal discourse of universal human rights circumvents critique by avoiding contextual questions, particularly those concerning economic globalization. The term "discourse" refers to the argument that language is not merely a way of describing external reality - a technique for labelling objects - but acts to signify generalized, socially constructed categories of thought to which important social meanings and values are attributed. Discourses promote particular categories of thought and belief that guide our responses to the prevailing socioeconomic environment. In this sense, discourses lend structure to our experiences, and the meanings we give to our experiences. An example of this can be seen when we use the term "lawyer," which does not simply describe an individual by professional category but also invokes a bundle of other meanings, expectations and understandings that go far beyond mere empiricism. Included among these are assumptions about authority, fairness, social class, punishment, justice, legitimacy, erudition and notions of social order. Discourses therefore provide sets of values and beliefs that inform our social responses and actions, although not always selfconsciously. Professional and intellectual discourses are among the most influential in this respect. Crucially, as professional, intellectual and interest based groups move to "privatize" and institutionalize discourse - through the introduction of specialized language, images, concepts, and the institutionalization of knowledge - the veracity, reliability, integrity and authority of discourse "experts" is reinforced, while other voices from outside the discourse are marginalized, derided, excluded and sometimes prohibited (Hunt 1993). The most prominent voices within the human rights discourse are lawyers, NGOs, and academics, whose authority ensures that the "true" discourse is maintained.

Discourses, therefore act as the meeting place for power and knowledge (Foucault, 1977). While neoliberals assume that knowledge can flourish only in the absence of power, from the perspective of discourse, there can be no knowledge without power or power in the absence of knowledge (Cozens Hoy, 1995). Any investigation into 
the truth-claims emanating from discourse must therefore include an enquiry into power. However, such an investigation does not imply that the generation of truth is necessarily corrupted by power but, rather, that the social world described by discourses always involves power relations. In this sense, neoliberal concerns that power can be defined in terms of legitimacy and illegitimacy misses the important point that even the legitimate exercise of power also excludes, marginalizes, silences, and prohibits alternatives.

Mutua illustrates this clearly in his discussion of the human rights discourse, which he argues is often expressed through images of the "saviour" overthrowing the "savage" to restore human rights to the "victim" (Mutua, 2002). While the image of good triumphing over evil to save the wretched may inspire a sense of moral righteousness, it fails to acknowledge that the wretched may aspire to an alternative view of dignity, rights and the good life than that promoted by the saviour. Within the context of the current global order, the saviour is concerned to promote the values, norms and principles of the dominant discourse of human rights, which is associated with the neoliberal project for economic globalization. The victim, on the other hand, may harbour other expectations, perhaps group rights and the right to cultural identity, which the neoliberal project finds difficulty in accommodating (Evans, 2000).

\section{Three discourses of universal human rights}

Following this approach to discourse suggests that human rights are better understood as three overlapping discourses - the philosophical, the legal and the political - each with its own language, concepts and normative framework.

At the centre of the philosophy of rights discourse is the project to discover secure foundations upon which universal claims for human rights might be sustained. This project has seen investigations into many possibilities, including the existence of a deity, human need, self-evidence and theories of justice. In the most recent period, where the values of liberalism have achieved a global reach, the tradition of natural rights has accomplished an unchallenged, though often unspoken, place as the rationale for building the post-World War II global human rights regime. Claims that all rational nations now subscribe to the "settled norm" of human rights (Frost, 1996), and that "amazing progress" has been achieved in recent decades (Opsahl, 1989), reinforce this view. Together, the idea of the "settled norm" and the still prevalent naturalist account of human rights, suggest the discovery of a final "truth," making all further foundationalist enquiry redundant. Indeed, the president of the United Nations General Assembly once noted that the "quest for the basis of human rights to which philosophers, jurists and politicians devoted their interest and concern in the past ... [has] lost its significance" (Chandler, 2002). For critics, this conclusion is part of a "culture of contentment" that assumes discourse "closure" is possible and desirable, rather than an alternative understanding of discourse as inexorable process (Gill, 1995). For some commentators, this error marks the contemporary philosophy of rights discourse as "as much round and round as ever forward" (Evans, 2003; Vincent 1986), as a point of "arrival” for neoliberal cosmopolitanism, rather than a point of "departure" towards new ways of conceptualizing rights and social order (Raphael, 1966), and as a conservative rather than a radical project (Carver, 1998). 
In contrast to the moral abstract nature of the philosophical discourse, the legal discourse focuses upon a large corpus of international human rights law, mostly generated under the auspices of the United Nations. The legal discourse focuses upon the internal logic of the law, its elegance, coherence, extent, and meaning, which the application of legal reason is said to reveal (Vincent, 1986). A second aspect of the legal discourse investigates questions concerning the extent to which human rights law can be said to have transformed the principles of international law into a system perhaps more appropriately labelled transnational law (Cassese, 1990). The purpose of this move is to resolve the contradictions between the cosmopolitan claims of human rights and the principles of sovereignty, non-intervention and cultural difference, upon which the international system and international law is built. Although this move may have noble motives, critics argue that it "impedes the application of basic international legal doctrine to human rights law; impedes its conceptual and academic development and obscures conflicts between the two" (Chinkin, 1998). In common with natural rights foundationalism, which, reason reveals, stands above the values that describe any particular society, culture or civilization, international human rights law claims to articulate a set of "neutral" values to which all reasonable people should subscribe (Marks, 1998).

Lastly, the political discourse seeks to contextualize the prevailing values expressed in law and philosophy. It is, therefore, concerned with questions of power and interests associated with the dominant conception of human rights and the expression of those interests as legal and philosophical "truths" (Evans, 1996; Stammers, 1993). While the application of reason and claims of neutrality have tended to legitimate the historic contribution of philosophy and international law, the political discourse is often seen as a value-laden, ideological project; a potential cause of conflict over human rights rather than a source of further "progress". From both the philosophical and legal perspective, to take account of power and interests in the human rights discourse raises the spectre of old conflicts over foundationalism, fosters doubts about "settled norms" (Frost, 1996), offers comfort for cultural relativists, raises questions over the legitimacy of international law, and thus threatens to bring down the whole post-World War II project for universal human rights. The political discourse is, therefore, treated with suspicion.

In response, those engaged in the political discourse argue that the failure to include an account of power and interests obstructs further investigation into human rights within a changing world order. Mutua, for example, argues that the "end of history” thesis promoted by Fukuyama and others (Fukuyama, 1992), which proclaims the triumph of particular truths over all previous heretical doctrines, fails to understand the dynamic nature of social formation:

Mutua argues that the human rights movement is still young a; its youth gives it an experimental status, not a final truth. The major authors of human rights discourse seem to believe that all the most important human rights standards and norms have been set and that what remains of the project is elaboration and implementation. This attitude is at the heart of the push to prematurely cut off debate about the political and philosophical roots, nature, and relevance of the human rights corpus (Mutua, 2002). 
Put simply, it can be argued that the legal discourse plays the dominant role, while the philosophical discourse has atrophied and the political discourse is marginalized. The often stated assertion that the "major deficiency of the regime in the eyes of many professional observers is poor compliance to the purposes of a treaty" reflects a commonly held perspective that the failure of human rights is a failure of international law (Dunér, 2002, emphasis original). When failures are identified the normal reaction is to create more international law, rather than question the wisdom of focusing so singly on the legal approach itself. Although continued reports of gross violations of human rights arouse some feelings of pessimism, the dominance of the international law brings many commentators to the conclusion that a rights based international order is not only possible but has already made considerable "progress".

While there is still much work to do, the literature reflects a view that the normative power of rights, together with the development of an extensive system of international law on human rights, provides a clear indication of steady "progress" towards achieving the aims of the regime. While there is still much work to do, the literature reflects a view that the normative power of rights, together with the development of an extensive system of international law on human rights, justifies this conclusion.

The habit of assuming that human rights are best understood as a singular, legal discourse, a discourse upon which general agreement has been achieved, therefore conceals important and continuing disagreements that are seldom confronted. Most importantly, the substitution of legal norms for human rights norms, reinforced by drawing a line under the philosophical discourse and denying the political discourse, offers an illusion of concord that is often inconsistent with political struggles associated with identity and difference.

\section{Disciplining Global Civil Society}

If the assertion that there actually exists a global consensus on human rights is correct, theory and practice would be in harmony, assuming that international law represented an accurate reflection of that consensus. Questions of power and interest would not arise because the human rights regime, through the medium of international law, would express the interests of all, rather than the interests of particular groups. However, an increasing number of scholars argue that it is no longer acceptable that we view the human rights discourse as a straightforward articulation of moral evolution in the twentyfirst century, as those who evidence the Universal Declaration and the major covenants are prone to assert (Langlois, 2001). If this assessment is apposite, and claims of global agreement are indeed premature, then the privileging of the human rights regime as a solution to an imagined consensus raises many questions. What, for example, is the role of international human rights law in the global order? Why is international law so privileged within the discourse of human rights if no consensus exists? What interests does the privileging serve?

An insight into these questions can be gained through the concept of "discipline," which is closely related to that of discourse. Discipline refers to a mode of social organization that operates without the need for coercion. It is a form of modernist power 
that imbues the individual with particular ways of thinking, knowing and behaving, thus instilling modes of social consciousness that make social action predictable. Discipline is learned and practiced in the day-to-day complex of social life, through institutional training received, for example, in the school, the university, the workplace, the church and the socioeconomic institutions found within civil society, where notions of correct and incorrect behaviour and thought are clearly delimited. The epithet "common sense" is achieved when a particular mode of thought and conduct is unquestioningly accepted as normal (Gramsci, 1996) This is not to argue that the disciplines cannot be defined as systems of rules, but these are not necessarily the rules articulated within the pages of international law. Instead, these rules are concerned with "norms" and the generation of "normalization" (Foucault, 1994). In this sense, the disciplines, which are the domain of global civil society, operate without need of compulsory obligation, but nevertheless exert a collective pressure that brings objective results in the form of customs and ways of thinking, knowing and acting (Gramsci, 1996).

The maintenance of disciplinary power is conducted through processes of data collection, through the observation, recording, measuring, inspecting, reporting, and monitoring, which today are more easily facilitated by systems of electronic data collection. Data accumulated from the observation of large numbers defines the "normal," opening the possibility of specifying the attributes of "acceptable" and "unacceptable" behaviour within the values, terms and language of dominant discourses of truth. Those who violate the norms of acceptable behaviour are therefore identifiable, enabling appropriate sanctions to be applied, while those who conform are rewarded. Foucault argues that the form of disciplinary power operating within the contemporary world order emerged during the eighteenth century, noting ironically that "the Enlightenment, which discovered the liberties, also invented the disciplines" (Foucault, 1977, p. 222).

While the idea of discipline may suggest a social order rife with ideological intent and conspiracy, such a conclusion would be a mistake (Prado, 1995). Instead, the conceptualization of discipline is an attempt to understand the ways in which knowledge is accumulated, and truth and rights established as the foundation for legitimate social action. From the perspective of discipline as social knowledge, power is not located within governments or particular factions, classes, institutions or cadres, but is instead exercised in the actions of everyday life. In contrast to the pre-modern period, where the exercise of power was associated with a readily identifiable agent, who operated irregularly and intermittently, modern forms of disciplinary power operate continuously and without agency. The distinctive nature of disciplinary power is that it replaces violence and the threat of violence with more temperate modes of action associated with visibility through surveillance (Fraser, 1995). This is not to argue that we can expect violence and the threat of violence to play no further role in the contemporary world order. As Robert Cox has observed, there may still be times when disciplinary power breaks down:

To cope with the excluded and potentially disruptive, the institutions of global governance have devised instruments of global poor relief and riot control. Humanitarian assistance (the poor relief component) has become a top priority of the United Nations and a major activity of a vast range of 
nongovernmental agencies. Where poor relief is inadequate to prevent political destabilization, then military force (the riot control component) is evoked by the international community. Together, they help to sustain the emerging social structure of the world by minimizing the risk of chaos in the bottom layer (Cox, 1997).

From the perspective of disciplinary power, critics of neoliberal notions of power have argued that the institutionalization of discourse, which produces and promotes truthclaims, obscures and conceals the processes of domination that lie beneath normal social practice (Ivison, 1998). Gill refers to the most prominent of the disciplines within the current global order as "market discipline," which stresses economic growth and development, deregulation, the free market, the privatization of public services and minimum government (Gill, 1995). Market discipline describes a set of normative relationships with a global reach, supported by discourses of truth, and widely accepted as "common sense". These relationships are manifest at both the domestic and global level, for example, in national and international economic planning, market-based solutions for environmental degradation, the move to privatize social welfare provision, and the move to privatize life itself, seen in the scramble to patent the genes of both human and non-human life forms. Surveillance is undertaken by international and regional agencies, for example, the World Trade Organization (WTO), the World Bank, the European Union (EU) and the North American Free Trade Agreement (NAFTA). Each of these is understood as the authentic voice of market discipline and each exercises systems of surveillance and data collection on a global and regional scale.

Within the remit of market discipline, as opposed to that of international law, human rights are conceptualized as the freedoms necessary to maintain and legitimate particular forms of production and exchange. These are a set of negative rights associated with liberty, security and property, which offer a moral and normative foundation for justifying actions within the current global political economy. Although the global human rights regime is said to embrace the unity of all rights, market discipline pursues only those rights necessary to sustain legitimate claims for neoliberal freedoms. The catalogue of rights associated with market discipline therefore describes human beings as individuals and agents of a particular kind and type. For critics, the human rights regime is partial. It represents the "Eden of the innate rights of man" where free will, equality within exchange relations and property converge to create social relations characterized by selfishness, gain and private interests, rather than the pursuit of human dignity and community (Marx, 2002, p. 492).

Following from this, several authors have argued that human life is valued as a means to an end, rather than an end in itself (Watkins, 1996). This is seen in the greater attention given to trade, property and finance, compared to that concerned with humanitarian issues, for example, poverty, the environment and socioeconomic rights. For critics, market discipline implies that "profit for investors [is] the supreme human value, to which all else must be subordinated," so that "[h]uman life has value as far as it contributes to this end" (Chomsky, 1994). The creation of authoritative international organizations provides the professionalized voice for truth-claims, performs the task of surveillance, ensures adherence to market disciplinary norms, and acts to maintain a particular set of rights and freedoms that are integral to sustaining a particular order. If 
human rights have any significance within the contemporary global order, they offer a set of values delimited by an assumed normative consensus that legitimates activities associated with market discipline, specifically, negative rights and those associated with property.

The poor social conditions characteristic of subordinating human rights to economic interests leads the disadvantaged, dispossessed, marginalized and excluded to organize politically, perhaps by creating independent trade unions and citizen groups to resist the harsher consequences of market discipline. In such cases, violence and the threat of violence is often used against those daring to voice a contrary view that challenges market disciplinary principles and the neo-liberal rationale for economic development (Evans, 2001). Since all governments take neoliberal notions of economic growth and development as a central policy objective, the deprivations suffered by those whose environment is degraded, culture devastated, freedom to protest peacefully suppressed and traditional ties with the land forcibly severed are seen less as the victims of human rights violations and more as the generation who must bear the cost of economic progress for the good of the wider, future community (Kotheri, 1994; Tomasevski, 1993). Those who continue to protest are referred to pejoratively as insular, conservative, traditionalists, clinging tenaciously to a cultural past, and resolutely denying the benefits of modernization to the next generation.

\section{Market Discipline, Normalization and the Human Rights Regime}

Market discipline may now be seen as "counter-law"; as a guide for action that stands above the international human rights regime. However, it does not follow that international law is of little consequence for market discipline. On the contrary, the regime legitimates claims that human rights are now at the centre of the new global order. International law, and international human rights law in particular, plays a central role in an emerging "constitutional” global order, which seeks to normalize a common identity (Gill, 1995). The dominance of the human rights regime, and the marginalization of the philosophical and political discourses of rights, provides a sense of "closure" that discourages further investigation. Thus, while criticism is commonly found in the literature on human rights, such criticism is confined to disagreements within a framework of rights that seldom attract critique. In short, in as much as the politics of rights is considered at all, what passes for politics is framed within a set of rules that are incontrovertibly accepted, while the framework itself remains unquestioned.

The tension between the formal/legal human rights regime and the norms of market discipline are at their most visible within global civil society. In particular, the notion of "civility" emanating from global civil society narrows the political agenda, excludes some groups from full participation, and acts as a focus for further political struggles. Stressing this point, Pasha and Blaney argue that the effort to promote particular notions of civility, for example, by attempting to universalize a particular conception of democracy or human rights, adds to the sense of injustice, and generates a politics that challenges the rules of civility (Pasha and Blaney, 1998). In other words, the more vigorously global civil society promotes market discipline, and its associated human rights values, the greater the resistance, creating a "periodic and irresolvable 
problem of policing the non-civil in civil society" (Pasha, forthcoming). Those who adhere to the norms of civility, and aspire to the ends promoted by global civil society, are included, while those who offend against the "normal," perhaps through critique, reflective alternatives or a stubborn refusal to abandon the cultural traditions of the past, are excluded. Disapproval may be registered by the agencies of global civil society in a number of ways, for example, by including aid conditionalities that emasculate government decision-making powers, by threatening intervention, by simply labelling alternative voices "mad" (Keeley, 1990), or by asserting that the excluded do not possess the moral capacity to engage fully in decision-making processes about their own best interests (Hindess, 1992).

At the forefront to the shift towards a singular notion of civility are transnational professional, business and financial organizations, which have grown in number and power under conditions of globalization. These groups are mindful that the interests of global production, trade and finance depend as much upon the capability to influence the rules governing the market as it does on competition and good business planning. For example, in 1997 the chief executives of ten major transnational corporations met with UN leaders, and high ranking government officials from several countries, to discuss appropriate ways for corporations to engage with UN agencies in planning new rules and institutions for global governance. A further example is seen in the activities of the International Chamber of Commerce, which has identified environmentalist, human rights and social protection groups as a possible threat to the further expansion of corporate activities and has moved to gain as much influence at the UN as possible to counter these forces (Millen, et al., 2000). Similarly, the Australian delegation at the Uruguay Round of talks on world trade included eight representatives of business but rejected all attempts by nongovernmental organizations with an interest in human rights to gain a seat (ChristianAid, 1999). A final example is seen in Cargill's involvement in developing the USA's negotiating position during the Uruguay Round. Christian Aid reports that the corporation, which controls half the global trade in grains, was given responsibility for the final draft of the policy document (ChristianAid, 1999). The history of corporate-government relations is therefore one characterized by corporate pressure to expand corporate rights, not those rights expressed in the human rights regime.

\section{Conclusion}

The human rights regime therefore supports competing understandings that give focus to deep-rooted political struggles. While the formal, institutionalized and legal regime is presented as guaranteeing the protection of human rights, the informal, privately motivated and extra-legal activities associated with "normal” global practice suggest that the values of market discipline take precedence.

Several conclusions might be drawn from this discussion on the relationship between the global political economy and human rights. First, within the complex of global governance and market discipline, the human rights regime plays an important role by defining a broad set of civil, political, social, economic and cultural rights. The inclusiveness that this broad spectrum of rights offers is, however, chimerical. The rules and norms that act to guide action at the global level are not to be found within the pages 
of international human rights law, as the assertions of lawyers, political leaders, NGO activists and many scholars assume. Rather, global action is guided by the norms defined by "market discipline". These norms have achieved widespread acceptance as "common sense" within the populations of advanced economies, and are widely accepted by influential decision-makers in less developed countries. International human rights law, which dominates the global human rights discourse, serves to obfuscate the real power relations characteristic of the current, globalizing world order. In short, historically the interests associated with neoliberal economic expansion trump human rights interests and will continue to do so.

Second, the legal human rights discourse assumes that a global consensus on a particular conception of rights already exists. Despite the popular belief that in most regions of the world the objective of human rights and democracy is accepted as a desirable and achievable policy objective (Conley and Livermore, 1996), little evidence is offered for such assertions. The rights referred to in these claims assume a particular conception of rights, defined as the freedom of the individual to invest time, capital and resources in processes of production and exchange (Tetrault, 1988). However, while it may be possible to claim that all regions of the world now embrace the concept of human rights, there can be no certainty that the conception of human rights associated with market discipline has achieved universal acceptance. While there may now be a clamour for human rights globally, we might ask how do we know that this is the same conception of rights currently expressed in international law?

Third, the emphasis on the legal discourse acts to mask the causes of human rights violations. The professional and intellectual discourse of law provides the "authentic voice" in human rights talk, although this voice has little to say about power and interests. As the dominant voice, the legal discourse also subordinates alternative voices with an interest in exposing the causes of human rights violations, many of which are attributable to global structures that are sustained by market discipline. In this way, international law plays an important structural role within a global order that increasingly stresses freedoms associated with business, finance and trade. The structures and practices that flow from these norms produce patterns of inclusion and exclusion peculiar to market discipline, including patterns of human rights violations. Many examples of this phenomenon are offered in the literature on globalization.

But, as Roy Bhaskar has argued, human rights and human emancipation "depends upon the transformation of structures rather than just the amelioration of states of affairs" (Bhaskar, 1991), which is a task most suited to international law. Similarly, both Katerina Tomaseviski and Christine Chinkin have stressed that while international law may have a capacity for redressing consequences, it cannot address causes (Chinkin, 1998; Tomasevski, 1993, p. 222). This is to argue that structures cannot be judicial persons with intentions and capabilities, nor can they be arrested, put before a court, punished for their crimes or subjected to sanctions. The dominance of the legal discourse, therefore, masks the real power structures that lie at the heart of many human rights violations. Put another way, we should exercise caution if we are to avoid confusing the "sites" of violations with the "causes" of violations.

One issue should be made clear. The argument here should not be seen as opposed to the idea of universal human rights. Rather, the purpose of the discussion has been to place the discourse(s) of human rights within the context of the global political economy. 
Perhaps the most important conclusion to be drawn from this discussion is that the discourse of human rights is not a singular discourse of freedom, but is also one of oppression. It is a discourse for emancipation and for disciplining global society. 


\section{References}

Bhaskar, R. (1991). Philosophy and the Idea of Freedom. Oxford: Blackwell.

Carver, T. (1998). The Postmodern Marx. Manchester: Manchester University Press.

Cassese, A. (1990). Human Rights in a Changing World. Oxford: Oxford University Press.

Chandler, D. (2002). From Kosovo to Kabul: Human Rights and International Intervention. London: Pluto Press.

Chimini, B.S. (1999). Marxism and International Law. Economic and Political Weekly 34, 349-49.

Chinkin, C. (1998). International Law and Human Rights. In T. Evans' (Ed.), Human Rights Fifty Years On: A Reappraisal (pp. 105-29). Manchester: Manchester University Press.

Chomsky, N. (1994). World Orders, Old and New. London: Pluto.

Christian Aid. (1999). Fair Shares? Transnational Corporations, the WTO and the Worlds Poorest Communities. Christian Aid.

Conley, M \& Livermore, D. (1996). Human Rights, Development and Democracy. Canadian Journal of Development Studies XIXI, 19-26.

Cox, R. (1997). Democracy in hard times: economic globalization and the limits to liberal democracy. In A. McGrew (Ed.) The Transformation of Democracy (pp. 49-75). Cambridge: Polity Press.

Cox, R. (1999). Civil Society at the turn of the Millennium: Prospects for an Alternative World Order. Review of International Studies.

Cozens Hoy, D. (1995). Power, Repression, Progress: Foucault, Lukes, and the Frankfurt School. In B. Smart (Ed.), Michel Foucault: Critical Assessments (pp. 173-91). London: Routledge.

Dunér, B. (2002). The Global Human Rights Regime. Lund: Studentlitteratur.

Evans, T. (2001). If Democracy, then Human Rights? Third World Quarterly 22, 623-42.

Evans, T. (1996). US Hegemony and the Project of Universal Human Rights. Basingstoke: Macmillan.

Evans, T. (2000). Citizenship and Human Rights in the Age of Globalization. Alternatives 25, 415-438.

Evans, T. (2003). Universal Human Rights: As Much Round and Round As Ever Forward. International Journal of Human Rights 7, 155-68.

Foucault, M. (1977). Discipline and Punish. (S.A, Trans.). New York: Pantheon Books.

Foucault, M. (1994). Two Lectures. In M. Kelly (Ed.), Critique and Power: Recasting the Foucault/Able Debate (pp. 1-46). Cambridge, MA: MIT Press.

Foucault, M. (1996). What is Critique? In J. Schmidt (Ed.), Twentieth-Century Questions (pp. 383-98). Berkley: University of California Press.

Fraser, N. (1995). Michel Foucault (2): Critical Assessments. In B. Smart (Ed.), Foucault on Modern Power: Empirical Insights and Normative Confusions. (pp. 133-48), vol. 2. London: Routledge.

Freeman, M. (2002). Human Rights. Cambridge: Polity Press.

Frost, M. (1996). Ethics of International Relations: A Constitutive Theory. Cambridge: Cambridge University Press.

Fukuyama, F. (1992). The End of History and the Last Man. New York: Free Press.

Gill, S. (1995). Globalization, Market Civilisation, and Disciplinary Neoliberalism. Millennium: Journal of International Studies 24, 399-423.

Gramsci, A. (1996). Selections From the Prison Notebooks. Q. Hoare \& G. Smith (Eds.). London: Lawrence and Wisehart.

Held, David, McGrew, A., Goldblatt, D and Perraton, J. (1999). Global Transformations: Politics, Economics and Culture. Cambridge: Polity Press.

Hindess, B. (1992). Power and Rationality: The Western Conception of Political Community. Alternatives 17, 149-63.

Hormats, R. (1998). Globalization and Human Rights. Public Broadcasting Service.

Hunt, A. (1993). Explorations in Law and Society: Towards a Constitutive Theory of Law. New York/London: Routledge.

Ivison, Duncan. (1998). The Disciplinary Moment: Foucault, Law and the Reincription of Rights. In The Later Foucault: Politics and Philosophy (pp. 129-48) J. Moss (Ed.). London: Sage.

Keeley, J. (1990). Towards a Foucauldian Analysis of International Regimes. International Organization 44, 83-105.

Kotheri, S. (1994). Global Economic Institutions and Democracy: A View from India. In Beyond Bretton Woods (pp. 39-54), J. Cavanagh, D. Wysham and M. Arrunda (Eds.), London: Pluto Press. 
Langlois, A. J. (2001). The Politics of Justice and Human Rights: Southeast Asia and Universalist Theory. Cambridge: Cambridge University Press.

Linklater, A. (1998). The Transformation of Political Society. Cambridge: Polity.

Marks, S. (1998). From the "Single confused Page" to the "Decalogue for Six Billion People": The Roots of the Universal Declaration of Human Rights in the French Revolution. Human Rights Quarterly 20, 449-514.

Marx, K. (2002). Karl Marx: Selected Writings. Oxford: Oxford University Press.

Mieville, C. (2006). Between Equal Rights: A Marxist Theory of International Law. London: Pluto Press.

Millen, J. V., Lyon E. and Irwin, A. (2000). Dying for Growth: The Political Influence of National and Transnational Corporations. In J. Y. Kim, J. V. Millen, A. Irwin and J. Gershaw (Eds.). Dying For Growth: Global Inequality and the Health of the Poor, (pp. 225-233) Monroe: Cameron Courage Press.

Mutua, M. (2002). Human Rights: A Political and Cultural Critique. Philadelphia: University of Pennsylvania Press.

Opsahl, T. (1989). Instruments of Implementation of Human Rights. Human Rights Law Journal 10, 13-33.

Pasha, M. K. Forthcoming. Liberalism, Islam, and International Relations. In E. G. Jones (Ed.), Decolonising International Relations. London: Rowman and Littleman.

Pasha, M. K. and Blaney, D. L. (1998). Elusive Paradise: The Promise and Perils of Global Civil Society. Alternatives 23, 417-540.

Prado, C.G. (1995). Starting with Foucault: An Introduction to Genealogy. Boulder: Westview.

Raphael, D.D. (1966). The Liberal Western Tradition of Human Rights. International Social Science Journal 18, 22-30.

Rouse, J. (1994). Power/Knowledge. In G. Cutting (Ed.), The Cambridge Companion to Foucault (pp. 92114). Cambridge: Cambridge University Press.

Scholte, J. A. (1996). Towards a Critical Theory of Globalization. In E. Kofman and G. Young (Eds.), Globalization in Theory and Practice (pp. 43-57). London: Pinter.

Spybey, T. (1996). Globalization and World Society. Cambridge: Polity Press.

Stammers, N. 1993. Human Rights and Power. Political Studies XLI, 70-82.

Taylor, C. (1995). Foucault on Freedom and Truth. In B. Smart (Ed.) Michel Foucault (2): Critical Assessments, vol. 2 (pp. 326-51). London: Routledge.

Tetrault, M. A. (1988). Regimes and Liberal World Order. Alternatives 13, 5-26.

Tomasevski, K. (1993). Development Aid and Human Rights Revisited. London: Pinter.

United Nations Development Programme. (1997). Human Development to Eradicate Poverty (Human Development Report 1997). Oxford: United Nations Development Programme.

United Nations Development Programme. (1999). Globalization with a Human Face (Human Development Report 1999). Oxford: United Nations Development Programme.

Vincent, R.J. (1986). Human Rights and International Relations. Cambridge: CUP.

Watkins, K. (1996). The Oxfam Poverty Report (p. 250). Oxford: Oxfam. 